\title{
The impact of government policies on Nigeria economic growth (case of fiscal, monetary and trade policies)
}

\author{
Olufemi Samuel Adegboyo ${ }^{*}$, Sunday Anderu Keji and Oluwadamilola Tosin Fasina
}

\begin{abstract}
This study examines the impact of fiscal, monetary and trade policies on Nigerian economic growth from 1985 to 2020. This study adopts endogenous growth model (AK model) as its theoretical framework. The unit root test results reveal that there is mixed level of stationarity in the variables. The bound test result shows that the variables cointegrate. The ARDL long-run result shows that fiscal policies stimulate economic growth, while on the contrary, trade policies deter Nigerian economic growth. The short-run result shows that the fiscal policies has an inconsistent impact on Nigerian economic growth and thus differs from the long-run result; while government spending continues to drive economic growth in Nigeria, government revenues have no effect on the growth of the economy. The result of the impact of monetary policies shows that interest rate impels growth of the economy while money supply deters growth of Nigeria's economy; lastly, the trade policies maintain her negative influence on the economy in both the long run and short run. Sequel to the findings, the study recommends the following: Policymakers should place more emphasis on using fiscal policy which was found to be stimulating the country's growth rate. Whenever it is expedient to use monetary policy to stimulate economic growth, policy makers should make use of interest rates as it stimulates the growth of the economy in the short run. The government should review her trade policies to reduce import by encouraging consumption of local products and motivate exporters of goods (raw material) to refine the products before exporting such.
\end{abstract}

Keywords: Fiscal policy, Monetary policy, Trade policy, And economic growth

JEL Classification: E52, F13, H3, O40, 047

\section{Introduction}

The fundamental roles of fiscal policy, monetary policy and trade policy cannot be over-emphasized in any open economy, especially in terms of economic management. Notably, the quests to achieve and sustain macroeconomic objectives explain the vital roles played by fiscal, monetary and trade policies in both developed and developing economies, which Nigeria is inclusive. Babar [1] noted that it is the goal of any rational government to improve the living conditions of her populace through major economic policy either through fiscal, monetary

${ }^{*}$ Correspondence: Olufemi.adegboyo@fuoye.edu.ng

Department of Economics, Federal University Oye-Ekiti, Oye-Ekiti, Nigeria or trade policy. Again, these economic policies are mostly used to stabilize and sustain the economic progression, especially during the period of economic crisis. For example, fiscal policy measure is used by government of different economies to counter economic imbalances by adjusting the public spending to moderate taxation which is an important approach to control aggregate demand, financial uncertainty and economic distortions. Keynes posited this approach need to be adopted, especially during economic recession so as to build a stable framework to attain full employment; hence, this theoretical model had been practically used as policy guide to sustain economic activities over time [2]. Meanwhile, the classicalists argued for effective price mechanism where 
efficient and robust resources allocation can guarantee economic freedom that is devoid of government intervention in the cause of addressing economic crisis [3]. On the other hand, monetary policy is adopted by the Apex Bank of any given economy to stimulate collective demand through adjustable changes in money supply and interest rate. In the time of economic crisis, government combines both fiscal and monetary policies to curb fluctuations of business cycle. In a similar vein, government put in place trade policy with the aim of improving trade relation and builds the necessary safety net against external shocks through stabilized exchange rate.

Over the years, many developing economies have been facing the problem of huge fiscal, monetary and trade deficits, which Nigeria is inclusive. The insufficient and the nature of public goods such as infrastructure and utilities services hugely rely on the rate of government spending, which affect both the nature and condition of macroeconomic framework and fiscal sustainability in any small open economy. Fiscal policy, monetary policy and trade policy in Nigeria are characterized by profligacy, poor financial framework, which is strengthened by poor management of huge oil revenue that pose a threat to macroeconomic stability [3]. Relatedly, policy makers in Nigeria have implemented series of trade policies through various objectives, for example the export promotion strategy in 1981; exchange rate liberalization and trade liberalization in 1986; creation of Nigerian Export-Import in 1991; and several trade bilateral and multilateral agreements with different countries among others [4]. The main objectives of these trade policies are: to achieve Nigeria's macroeconomic stability and to improve trade nexus with the global community via hitch-free inflow and outflow of both liquidity and non-liquidity transactions across the borders, while these activities are expected to increase international competitiveness which in the long run could bring about an improvement in national economic growth [5]. However, in the time past, the Nigerian economic growth has not significantly tapped from those expected gains from trade policies which could have been traced to the mono-economic nature of the Nigerian economy where government mostly relied on oil revenue. This has caused incessant rise in budget deficit in recent times; hence, there is need for policy makers to adopt effective fiscal and monetary measures so as to stabilize the aggregate economic outlook. Notably, a persistent rise in military spending to counter terrorism and additional unproductive outlays might have contributed to slow economic growth in Nigeria. In the meantime, Idris and Ahmad [6] posit that continuous show of fiscal deficit in Nigeria may be connected to over dependency on gains from oil coupled with external borrowings. Consequently, significant effects of improved fiscal measures would increase aggregate growth which could curb persist ineffective monetary and fiscal policies. It is worth agreeing with the position of Khattry and Rao [7] which state that trade policy improves fiscal balances through rise in tax revenue. And this is expected to increase the size of government revenue that could be channeled to various productive sectors via government spending on infrastructure.

In lieu of the above narrative on the nexus between fiscal policy and economic growth, or nexus between monetary policy and economic growth, or relationship between trade policy and economic growth, it has been observed through the studies that increase in government spending and trade openness and decrease in interest rate have not transmitted to improved economic growth in Nigeria. Interestingly, further related studies have equally come up with mixed revelations. For example, Kemal et al. [8] conclude that regulated and restricted flow in the level of imports expand the nation's economic output, whereas Martes [9] observed that trade liberalization impact negatively on productivity rate. Again, Amassoma et al., [10] explained that monetary policy is a vital tool which could be used to achieve price stability, and hence strengthen both private and foreign investors that guarantees economic progress in the long. Also, Idris et al., [11] posit that robust and effective fiscal operations guarantee economic growth since any slight distortion in fiscal operation in the form of deficit brings adverse effect on growth rate, which further substantiate the epistemology method of neo-classical theory that posit growth-retarding effects on the general economic performance due fiscal deficit. With this narrative, it can further be observed that studies on the subject matter in Nigeria have come up with different results, but most of these previous works are not encompassing in terms of linking fiscal policy, monetary policy, trade policy and economic growth rather most of these works had either attempted to link monetary policy with economic growth or relate fiscal policy with economic growth. It is interesting to note that this study intends to fill the gap observed from previous studies through empirical investigation into the nexus between fiscal policy, monetary policy and economic growth in Nigeria. Going forward, series of questions arise, which this study seeks to address; thus, do fiscal, monetary, trade policies matter on economic growth? What is the nexus between economic growth and fiscal, monetary, trade policies in Nigeria? Therefore, 
the aim of this study is to empirically estimate the link between the key variables while the outcome from this study would further provide guide for both government and policy makers so as to address the current perennial economic recession in Nigeria.

The reviewed literature clearly shows evidence that there exists a paucity of knowledge as regard how the combined effect of different policies affect economic growth in Nigeria. The above studies have examined how either each of fiscal policy or monetary policy or trade policy affects economic growth in Nigeria. However, to the best of our knowledge, no existing study has examined the combined effect of fiscal policy, monetary policy and trade policy on economic growth using Nigeria as a case study. In addition, this is particularly pertinent as the Nigerian government continues to implement different policies aimed at achieving economic growth and stability but the economy continues to experience a low level of economic growth as indicated by the national bureau of statistics. Consequently, this study adds to the existing literature and gives an original contribution to knowledge by examining the impact of government policies (monetary, fiscal and trade policies) on economic growth in Nigeria so as to suggest viable recommendations to the Nigerian government.

The rest of the study is structured as follows: "Literature review" section addresses comprehensive literature review of the previous related studies; "Method" section deals with model specification and the research methods; "Results and discussion" section accounts for empirical analysis of the dataset; and lastly, "Conclusions" section explains the general conclusion drawn from the study and policy recommendations that could serve as a guide for the Nigerian government and other developing economies at large.

\section{Literature review}

There are various empirical studies conducted in the past which form the existing literature for the subject matter of this current study. Previous studies that relate to this current study are reviewed and categorized based on how each of the variables affects economic growth in Nigeria as presented in the existing literature. For instance, for the review of how fiscal policy affects economic growth, Agu et al. [12] examined how fiscal policy affects growth of Nigeria's economy with a focus on the different components of public spending using OLS estimation technique. They found that government spending increase with an increase of revenue generated by the government. The study concluded that the correlation between government spending and growth of the economy is a strong and positive one. Babalola and Aminu [13] investigated the effect of fiscal policy on Nigerian's economic growth from 1977 to 2009 . The study observed that productive expenditure positively influence the country's economic growth. The study therefore recommends that government should improve its spending on economic services, education and the health sector to boost the growth of the economy. Onwe [14] investigated the growth of Nigerian economy vis-à-vis effect of fiscal policy components on Nigerian economic growth. The study observed the positive impact of federal expenditure on administration as well as on community and social services on growth of the economy. However, it also observed the non-positive impact of federal spending on transfer payments and economic services on the growth of Nigeria's economy. The study recommended a need for federal government to place special emphasis on administrative, social and community services in its fiscal policies because these fiscal components have potential contribution in the development of the Nigerian economy. Mobolaji et al., [15] examined inclusive growth in Nigeria vis-à-vis the role of fiscal policy using a baseline regression model. They found that fiscal policy significantly promotes inclusive growth in Nigeria. The study also observed a unidirectional causal relationship from fiscal policy to inclusive growth in Nigeria. It recommended the need for government expenditure to be directed toward productive investments and infrastructural development in a bid to accelerate inclusive growth. Chinedu et al. [16] explored how sectoral spreads of government expenditure impacts Nigerian Economic growth employing an error correction model technique. It observed that economic performance in Nigeria was positively impacted by sectoral spreads of government expenditure. The study observed the statistical significance of government expenditure on agriculture and defense. However, the study also observed that there was no statistical significance for government expenditure on health, education, transportation and communication. The study recommended that political office holders should have the political will to transform Nigeria into a developed country through accountability and transparency in how public funds are used. For a review of how economic growth is affected by monetary policy, Ayomitunde et al. [17] examined how Nigerian economic growth is been affected by monetary policy for the years 1990 to 2017 using an ARDL Bound estimation technique. Findings showed monetary policy rate significantly propels growth of Nigeria's economy in the short 
run while inflation rate positively influence growth of Nigeria's economy in both the short and long run, there is a significant positive relationship between economic growth and inflation rate. They recommended that Apex Bank use monetary policy variables that help drive economic growth in Nigeria. Onyeiwu [18] explored how monetary policy affects Nigerian economic growth using OLS estimation technique. The findings showed that monetary policy stimulates gross domestic product cum balance of payment but adversely impact inflation rate. It recommended that monetary policy be used to create an investment-friendly environment and the money market should strive to provide financial instruments that meet the needs of increasingly numerous players.

Sulaiman and Migiro [19] investigated the nexus between growth of Nigerian economy and monetary policy. The study found that monetary policy supports economic growth, and the study also found that economic growth is unrelated to monetary policy. The study concluded that the mechanism for transmitting monetary policy makes a positive contribution to the productivity of the Nigerian economy, thereby improving economic growth. The study recommended that the regulatory framework for the financial sector be strengthened to contribute to the efficiency of the government's monetary policies. Adigwe et al. [20] studied how monetary policies in Nigeria affect the country's economic growth using the ordinary least square technique. The study observed that monetary policy promotes economic growth, while it adversely affected by inflation rate. The study recommended using monetary policy to foster an enabling investment environment through appropriate interest rates, liquidity management and exchange rates. Fasanya et al. [21] studied the effect of monetary policy on the growth of Nigeria's economy using the error correction model technique. The study found that monetary policy instruments such as the inflation rate, the exchange rate and foreign reserves boost growth in Nigerian economy in line with theoretical expectations while money supply in Nigeria is unrelated to economic growth. Consequently, the study recommended the establishment of primary and secondary government bond markets that would enhance the effectiveness of monetary policy and reduce the government's reliance on the central bank for direct financing. For a review of how trade policy affects economic growth, Afolabi et al. [22] researched the impact of trade (trade policy) on the growth of Nigeria's economy using the ARDL technique. They found that price-based variables and adjusted trade ratio positively influence gross domestic product in both long and short run. In the long run, dynamic responses showed that gross domestic product responded positively to trade policy. The study recommended the need for policy makers to implement policies aimed at promoting international trade and innovations. Afolabi et al. [23] researched how international trade affects growth of Nigeria's economy using the ordinary least square technique. The study found that government expenditure, interest rate, import and export exert positive impact while it observed that foreign direct investment and exchange rate have a negative significance impact on growth of Nigeria's economy. The study recommended that the country's trade should not be limited to primary and oil exports, but to the promotion of non-primary exports and non-oil exports as well. In addition, there are some studies that examined the combined effect of fiscal and monetary policy on economic growth in Nigeria. For instance, Bodunrin [25] examined how fiscal and monetary policies affect Nigerian economic growth using vector error correction model technique to determine which of the policies has been more effective in driving the growth in Nigeria. The study observed that in the short-run fiscal policy distort economic growth while monetary policy had no effect on gross domestic product. The study opined that fiscal policy should take the central stage in the use of policy options. Ajayi and Aluko [26] evaluated how efficient is monetary and fiscal policy in Nigeria employing OLS estimation technique. The study observed that export and money supply growth significantly stimulate economic growth while government spending had no impact. Also, the study found that monetary policy stimulates the growth more than fiscal policy. The study recommended the use of monetary policy by the Nigerian government rather than fiscal policy as an economic stabilization tool. Titiloye and Ishola [27] examined the effect of fiscal and monetary policies on growth of Nigeria economy using ARDL technique. The study found that supply of money vis-à-vis government spending cum revenue stimulates Nigerian economic growth. The study recommended that there is a need for the government to allow expansionary monetary policy to stabilize economic growth. 
Summary of literature:

\begin{tabular}{|c|c|c|c|c|}
\hline $\begin{array}{l}\text { Author/ } \\
\text { year }\end{array}$ & Topic & $\begin{array}{l}\text { Estimation } \\
\text { technique }\end{array}$ & Findings & Criticism \\
\hline $\begin{array}{l}\text { Agu et al. } \\
{[12]}\end{array}$ & $\begin{array}{l}\text { Fiscal } \\
\text { policy and } \\
\text { economic } \\
\text { growth in } \\
\text { Nigeria }\end{array}$ & $\begin{array}{l}\text { Ordinary } \\
\text { least square }\end{array}$ & $\begin{array}{l}\text { They } \\
\text { found that } \\
\text { government } \\
\text { spending } \\
\text { increase } \\
\text { with an } \\
\text { increase } \\
\text { of revenue } \\
\text { generated } \\
\text { by the gov- } \\
\text { ernment }\end{array}$ & $\begin{array}{l}\text { The study } \\
\text { focused only } \\
\text { on the impact } \\
\text { of fiscal policy } \\
\text { on economic } \\
\text { growth but } \\
\text { failed to } \\
\text { examine how } \\
\text { other policies } \\
\text { contribute } \\
\text { to economic } \\
\text { growth in } \\
\text { Nigeria }\end{array}$ \\
\hline $\begin{array}{l}\text { Babalola } \\
\text { and Aminu } \\
{[13]}\end{array}$ & $\begin{array}{l}\text { The rela- } \\
\text { tionship } \\
\text { between } \\
\text { fiscal policy } \\
\text { and growth } \\
\text { of Nigeria } \\
\text { economy }\end{array}$ & $\begin{array}{l}\text { Autoregres- } \\
\text { sive distrib- } \\
\text { uted lag }\end{array}$ & $\begin{array}{l}\text { The study } \\
\text { observed } \\
\text { that } \\
\text { productive } \\
\text { expenditure } \\
\text { positively } \\
\text { influ- } \\
\text { ence the } \\
\text { country's } \\
\text { economic } \\
\text { growth }\end{array}$ & $\begin{array}{l}\text { This study was } \\
\text { restricted to } \\
\text { the relation- } \\
\text { ship between } \\
\text { government } \\
\text { spending } \\
\text { (especially } \\
\text { productive } \\
\text { spending) } \\
\text { and growth } \\
\text { of Nigerian } \\
\text { Economy }\end{array}$ \\
\hline Onwe [14] & $\begin{array}{l}\text { Effect of } \\
\text { fiscal policy } \\
\text { components } \\
\text { on Nigerian } \\
\text { economic } \\
\text { growth }\end{array}$ & $\begin{array}{l}\text { Ordinary } \\
\text { least square } \\
\text { regression }\end{array}$ & $\begin{array}{l}\text { The study } \\
\text { observed } \\
\text { the positive } \\
\text { impact } \\
\text { of federal } \\
\text { expendi- } \\
\text { tures on } \\
\text { adminis- } \\
\text { tration as } \\
\text { well as on } \\
\text { growth of } \\
\text { Nigerian } \\
\text { economy }\end{array}$ & $\begin{array}{l}\text { It looked only } \\
\text { at the impact } \\
\text { of some } \\
\text { components } \\
\text { of public } \\
\text { spending } \\
\text { on Nigerian } \\
\text { economic } \\
\text { growth }\end{array}$ \\
\hline $\begin{array}{l}\text { Mobolaji } \\
\text { et al., [15] }\end{array}$ & $\begin{array}{l}\text { The role of } \\
\text { fiscal policy } \\
\text { on Nigeria's } \\
\text { growth }\end{array}$ & $\begin{array}{l}\text { Baseline } \\
\text { regression } \\
\text { model and } \\
\text { granger test }\end{array}$ & $\begin{array}{l}\text { They found } \\
\text { that fiscal } \\
\text { policy } \\
\text { significantly } \\
\text { promotes } \\
\text { inclusive } \\
\text { growth in } \\
\text { Nigeria }\end{array}$ & $\begin{array}{l}\text { The study } \\
\text { was limited } \\
\text { to inclusive } \\
\text { growth in } \\
\text { Nigeria }\end{array}$ \\
\hline $\begin{array}{l}\text { Chinedu } \\
\text { et al. [16] }\end{array}$ & $\begin{array}{l}\text { Sectoral } \\
\text { allocation of } \\
\text { government } \\
\text { spend- } \\
\text { ing and } \\
\text { economic } \\
\text { growth in } \\
\text { Nigeria }\end{array}$ & $\begin{array}{l}\text { Error correc- } \\
\text { tion model }\end{array}$ & $\begin{array}{l}\text { The study } \\
\text { found that } \\
\text { the break- } \\
\text { down of } \\
\text { government } \\
\text { spending by } \\
\text { sector has } \\
\text { a positive } \\
\text { impact on } \\
\text { Nigeria's } \\
\text { economic } \\
\text { perfor- } \\
\text { mance }\end{array}$ & $\begin{array}{l}\text { The study was } \\
\text { confined to a } \\
\text { sector-specific } \\
\text { approach } \\
\text { to public } \\
\text { spending and } \\
\text { its impact } \\
\text { on Nigerian } \\
\text { Economic } \\
\text { growth }\end{array}$ \\
\hline
\end{tabular}

\begin{tabular}{|c|c|c|c|c|}
\hline $\begin{array}{l}\text { Author/ } \\
\text { year }\end{array}$ & Topic & $\begin{array}{l}\text { Estimation } \\
\text { technique }\end{array}$ & Findings & Criticism \\
\hline $\begin{array}{l}\text { Ayomitunde } \\
\text { et al. [17] }\end{array}$ & $\begin{array}{l}\text { Monetary } \\
\text { policies and } \\
\text { Nigerian } \\
\text { economic } \\
\text { growth }\end{array}$ & $\begin{array}{l}\text { Error correc- } \\
\text { tion model }\end{array}$ & $\begin{array}{l}\text { Findings } \\
\text { showed } \\
\text { monetary } \\
\text { policy rate } \\
\text { significantly } \\
\text { propels } \\
\text { growth of } \\
\text { Nigeria's } \\
\text { economy } \\
\text { in the short } \\
\text { run while } \\
\text { inflation rate } \\
\text { positively } \\
\text { influence } \\
\text { growth of } \\
\text { Nigeria's } \\
\text { economy } \\
\text { in both the } \\
\text { short and } \\
\text { long run, } \\
\text { there is a } \\
\text { significant } \\
\text { positive } \\
\text { relationship } \\
\text { between } \\
\text { economic } \\
\text { growth and } \\
\text { inflation rate }\end{array}$ & $\begin{array}{l}\text { The study } \\
\text { places greater } \\
\text { emphasis on } \\
\text { the impact } \\
\text { of monetary } \\
\text { policy on } \\
\text { economic } \\
\text { growth while } \\
\text { disregarding } \\
\text { the effects of } \\
\text { other policies }\end{array}$ \\
\hline $\begin{array}{l}\text { Onyeiwu } \\
\text { [18] }\end{array}$ & $\begin{array}{l}\text { The impact } \\
\text { of monetary } \\
\text { policy on } \\
\text { Nigerian } \\
\text { economic } \\
\text { growth }\end{array}$ & OLS & $\begin{array}{l}\text { The study } \\
\text { found that } \\
\text { monetary } \\
\text { policy posi- } \\
\text { tively influ- } \\
\text { ence gross } \\
\text { domestic } \\
\text { product } \\
\text { growth }\end{array}$ & $\begin{array}{l}\text { This study } \\
\text { only exam- } \\
\text { ined the } \\
\text { impact of } \\
\text { monetary } \\
\text { policy on eco- } \\
\text { nomic growth } \\
\text { in Nigeria, } \\
\text { but did not } \\
\text { explain the } \\
\text { mechanism } \\
\text { behind the } \\
\text { relationship }\end{array}$ \\
\hline $\begin{array}{l}\text { Sulaiman } \\
\text { and Migiro } \\
{[19]}\end{array}$ & $\begin{array}{l}\text { The nexus } \\
\text { between } \\
\text { growth of } \\
\text { Nigerian } \\
\text { economy } \\
\text { and mon- } \\
\text { etary policy }\end{array}$ & $\begin{array}{l}\text { Granger } \\
\text { causality } \\
\text { test }\end{array}$ & $\begin{array}{l}\text { The study } \\
\text { found that } \\
\text { mon- } \\
\text { etary policy } \\
\text { supports } \\
\text { economic } \\
\text { growth, the } \\
\text { study also } \\
\text { found that } \\
\text { economic } \\
\text { growth is } \\
\text { unrelated to } \\
\text { monetary } \\
\text { policy }\end{array}$ & $\begin{array}{l}\text { The study } \\
\text { found that } \\
\text { economic } \\
\text { growth is } \\
\text { not related } \\
\text { to monetary } \\
\text { policy, but } \\
\text { failed to } \\
\text { explain the } \\
\text { reason for this } \\
\text { observation }\end{array}$ \\
\hline $\begin{array}{l}\text { Adigwe } \\
\text { et al. [20] }\end{array}$ & $\begin{array}{l}\text { The effect } \\
\text { of monetary } \\
\text { policies on } \\
\text { Nigerian } \\
\text { economic } \\
\text { growth }\end{array}$ & $\begin{array}{l}\text { Ordinary } \\
\text { least square } \\
\text { method }\end{array}$ & $\begin{array}{l}\text { The study } \\
\text { observed } \\
\text { that mon- } \\
\text { etary policy } \\
\text { promotes } \\
\text { GDP }\end{array}$ & $\begin{array}{l}\text { The study } \\
\text { doesn't have } \\
\text { an original } \\
\text { contribution } \\
\text { to knowledge }\end{array}$ \\
\hline
\end{tabular}




\begin{tabular}{|c|c|c|c|c|}
\hline $\begin{array}{l}\text { Author/ } \\
\text { year }\end{array}$ & Topic & $\begin{array}{l}\text { Estimation } \\
\text { technique }\end{array}$ & Findings & Criticism \\
\hline $\begin{array}{l}\text { Afolabi et al. } \\
\text { [22] }\end{array}$ & $\begin{array}{l}\text { Trade policy } \\
\text { and growth } \\
\text { of Nigerian } \\
\text { economy }\end{array}$ & $\begin{array}{l}\text { Autoregres- } \\
\text { sive distrib- } \\
\text { uted lag }\end{array}$ & $\begin{array}{l}\text { They found } \\
\text { that price- } \\
\text { based vari- } \\
\text { ables and } \\
\text { adjusted } \\
\text { trade ratio } \\
\text { positively } \\
\text { influence } \\
\text { gross } \\
\text { domestic } \\
\text { product in } \\
\text { both long } \\
\text { and short } \\
\text { run }\end{array}$ & $\begin{array}{l}\text { The study } \\
\text { concentrated } \\
\text { on the role of } \\
\text { trade policies } \\
\text { in achiev- } \\
\text { ing growth } \\
\text { in Nigerian } \\
\text { economy } \\
\text { while ignoring } \\
\text { the impact of } \\
\text { other policies }\end{array}$ \\
\hline $\begin{array}{l}\text { Afolabi et al. } \\
\text { [23] }\end{array}$ & $\begin{array}{l}\text { The impact } \\
\text { of trade on } \\
\text { growth of } \\
\text { Nigerian } \\
\text { economy }\end{array}$ & $\begin{array}{l}\text { Ordinary } \\
\text { least square } \\
\text { estimation } \\
\text { technique }\end{array}$ & $\begin{array}{l}\text { The study } \\
\text { found that } \\
\text { import and } \\
\text { export exert } \\
\text { positive } \\
\text { impact } \\
\text { while it } \\
\text { observed } \\
\text { that foreign } \\
\text { direct } \\
\text { invest- } \\
\text { ment and } \\
\text { exchange } \\
\text { rate have } \\
\text { a negative } \\
\text { impact on } \\
\text { growth of } \\
\text { Nigeria's } \\
\text { economy }\end{array}$ & $\begin{array}{l}\text { The study did } \\
\text { not provide } \\
\text { an in-depth } \\
\text { explana- } \\
\text { tion of how } \\
\text { foreign direct } \\
\text { investment } \\
\text { negatively } \\
\text { impacts eco- } \\
\text { nomic growth } \\
\text { in Nigeria }\end{array}$ \\
\hline $\begin{array}{l}\text { Bodunrin } \\
{[25]}\end{array}$ & $\begin{array}{l}\text { The effect } \\
\text { of monetary } \\
\text { and fiscal } \\
\text { policy on } \\
\text { growth } \\
\text { of Nigeria } \\
\text { economy }\end{array}$ & $\begin{array}{l}\text { Vector error } \\
\text { correction } \\
\text { model }\end{array}$ & $\begin{array}{l}\text { The study } \\
\text { observed } \\
\text { that in the } \\
\text { short-run } \\
\text { fiscal policy } \\
\text { distort } \\
\text { economic } \\
\text { growth } \\
\text { while } \\
\text { monetary } \\
\text { policy had } \\
\text { no effect } \\
\text { on gross } \\
\text { domestic } \\
\text { product }\end{array}$ & $\begin{array}{l}\text { The study } \\
\text { has not } \\
\text { established } \\
\text { whether } \\
\text { there is a link } \\
\text { between } \\
\text { monetary } \\
\text { policy and } \\
\text { fiscal policy } \\
\text { and how it } \\
\text { influences } \\
\text { economic } \\
\text { growth }\end{array}$ \\
\hline $\begin{array}{l}\text { Ajayi and } \\
\text { Aluko [26] }\end{array}$ & $\begin{array}{l}\text { Impact of } \\
\text { fiscal and } \\
\text { monetary } \\
\text { policies } \\
\text { on growth } \\
\text { of Nigeria } \\
\text { economy }\end{array}$ & OLS & $\begin{array}{l}\text { The study } \\
\text { observed } \\
\text { that export } \\
\text { and money } \\
\text { supply } \\
\text { growth } \\
\text { significantly } \\
\text { stimulate } \\
\text { economic } \\
\text { growth } \\
\text { while } \\
\text { government } \\
\text { spending } \\
\text { had no } \\
\text { impact }\end{array}$ & $\begin{array}{l}\text { The study } \\
\text { found that } \\
\text { mon- } \\
\text { etary policy } \\
\text { is a stronger } \\
\text { growth } \\
\text { driver than } \\
\text { fiscal policy } \\
\text { but failed to } \\
\text { explain the } \\
\text { reason why } \\
\text { it so in the } \\
\text { context of } \\
\text { the Nigerian } \\
\text { economy }\end{array}$ \\
\hline
\end{tabular}

\begin{tabular}{|c|c|c|c|c|}
\hline $\begin{array}{l}\text { Author/ } \\
\text { year }\end{array}$ & Topic & $\begin{array}{l}\text { Estimation } \\
\text { technique }\end{array}$ & Findings & Criticism \\
\hline $\begin{array}{l}\text { Titiloye and } \\
\text { Ishola [27] }\end{array}$ & $\begin{array}{l}\text { Effect of } \\
\text { monetary } \\
\text { and fiscal } \\
\text { policies on } \\
\text { Nigerian } \\
\text { economy }\end{array}$ & $\begin{array}{l}\text { Autore- } \\
\text { gressive } \\
\text { distributed } \\
\text { lag model }\end{array}$ & $\begin{array}{l}\text { The study } \\
\text { found that } \\
\text { supply of } \\
\text { money } \\
\text { vis-à-vis } \\
\text { government } \\
\text { spend- } \\
\text { ing cum } \\
\text { revenue } \\
\text { stimulates } \\
\text { Nigerian } \\
\text { economic } \\
\text { growth }\end{array}$ & $\begin{array}{l}\text { The study } \\
\text { concentrated } \\
\text { more on the } \\
\text { impact of } \\
\text { monetary } \\
\text { policy on } \\
\text { Nigerian } \\
\text { economic } \\
\text { growth }\end{array}$ \\
\hline
\end{tabular}

The reviewed literature clearly shows evidence that there is a paucity of knowledge as regard how the combined effect of different policies affects growth of the Nigerian economy. The above empirical studies examined how each of the policies (fiscal policy, monetary policy and trade policy) affects the growth of the Nigerian economy. However, based on the review of the literature, no empirical study has examined a combined effect of fiscal policy, monetary policy and trade policy on the growth of the Nigerian economy. In addition, this is particularly pertinent as the Nigerian government continues to implement different policies aimed at achieving economic growth and stability, but the economy continues to experience a low level of economic growth as indicated by the national bureau of statistics. Consequently, this study adds to the existing literature and gives an original contribution to knowledge by examining how government policies (monetary, fiscal and trade policies) affect the growth of the Nigerian economy and to suggest suitable recommendations to the Nigerian government. This serves as an original contribution to knowledge and the existing literature.

\section{Method}

The study adopts a model of endogenous growth (AK model) and the Cobb-Douglas production function as a theoretical framework. The production function is given in Eq. (1) that follows.

$$
Y=A K^{\alpha} L^{1-\alpha}
$$

where $\mathrm{Y}=$ economic production, $\mathrm{A}=$ technological advancement, $\mathrm{K}=$ capital stock, $\mathrm{L}=$ labor, and $\alpha$ and $1-\alpha$ are the vector parameters.

Dividing Eq. (1) all through by labor, the result is presented as Eq. (2)

$$
y=A k^{\alpha}
$$

where $\mathrm{y}$ is the economic output per labor, $\mathrm{k}$ is the capital per laborer, $\alpha$ is the vector parameters of capital stock per 
labor and A remains as it is unaffected by labor force or capital stock.

\section{Model specification}

The study is based on the assumption that policies influence technological progress, such that monetary policy, fiscal policy and trade policy influence technological progress.

$$
A=f(M P, F P, T P)
$$

Inserting Eq. (3) into Eq. (2) gives Eq. (4)

$$
y=f(M P, F P, T P) k^{\alpha}
$$

The study uses the money supply and the interest rate as indicators of monetary policy, public spending and revenue as indicators of fiscal policy while trade openness is used as a proxy for trade policy and incorporate them into the Eq. (4) to generate Eq. (5)

$$
y=f(M S, I N T R, G E X P, G R E V, T R O) k^{\alpha}
$$

Transforming Eq. (5) into econometrics form leads to Eq. (6)

\section{Data source}

The study employs annual time series data in the period of 1985-2020. The data were compiled mainly from the Statistical Bulletin of the Central Bank of Nigeria (CBN) and the World Development Indicators (WBI).

The definition and computation of variables vis-à-vis the source are presented in Table 1.

\section{A priori expectation and justification}

i. $\frac{\partial G D P P C}{\partial G D P P C(-1)}>0$; this implies that GDPPC(1) is expected to positively impact the GDPPC this is because the previous income level should positively affect the present income level in the country.

ii. $\frac{\partial G D P P C}{\partial G C F}>0$; this implies that the GCF should positively impact the GCPPC, because the capital stock should have a positive effect on the Nigeria's economic growth.

iii. $\frac{\partial G D P P C}{\partial G E X P}>0$; this implies that GEXP should positively impact the GCPPC, because government spending implies injection of fund to the public which will in turn increase the purchasing power

$$
G D P P C_{t}=\alpha_{0}+\alpha_{1} M S_{t}+\alpha_{2} I N T R_{t}+\alpha_{3} G E X P_{t}+\alpha_{4} G R E V_{t}+\alpha_{5} T R O_{t}+\alpha_{6} k_{t}+\varepsilon_{t}
$$

where $\mathrm{GDPPC}=$ gross domestic product per capital, MS = money supply (M2), INTR = interest rate, $\mathrm{GEXP}=$ Government expenditure, GREV $=$ Government revenue, $\mathrm{TRO}=$ trade openness, $\mathrm{k}=$ capital stock/GCF $\alpha_{0}$ to $\alpha_{6}=$ vector of the variables/parameters, $\varepsilon=$ error term and $\mathrm{t}=$ time trend. Equation (6) needs to be transformed for all the variables to have the same appropriate coefficient because interest rate and trade openness were in rate while other variables were in billions. Therefore, the variable that is in rate would be logged so the model would be in log-linear model form as presented in Eq. (7) of the citizens and consequently propel economic growth; also, it could be that the government is providing social infrastructure which is attracting investors and in turn propels economic growth.

iv. $\frac{\partial G D P P C}{\partial G R E V}>0$; this implies that GREV should positively impact the GDPPC, because as more revenue is generated, the government will have adequate fund to carry out its statutory functions, which in turn will contribute to the country's economic growth.

\begin{tabular}{|c|c|c|c|}
\hline Variable & Definition & Calculation/computation & Source \\
\hline$y / G D P P C$ & Gross domestic product per capita & GDP divided by population & WBI \\
\hline k/GCF & $\begin{array}{l}\text { Total capital stock is measured by } \\
\text { gross capital formation }\end{array}$ & $\begin{array}{l}\text { Consists of expenses related to additions to the fixed assets of the economy, plus net } \\
\text { changes in the level of inventories }\end{array}$ & WBI \\
\hline M2 & Money supply & $\begin{array}{l}\text { Consists of the sum of non-banked currencies, demand deposits, savings deposits, } \\
\text { money market securities and other term deposits }\end{array}$ & CBN Bulletin \\
\hline INTR & Interest rate & & CBN Bulletin \\
\hline GEXP & Total government expenditure & The sum of recurrent expenditure and capital expenditure & CBN Bulletin \\
\hline GREV & Government revenue & The sum of oil and non-oil revenues & CBN Bulletin \\
\hline TRO & Trade openness & $\begin{array}{l}\text { Trade is the sum of exports and importations of goods and services as a percentage of } \\
\text { gross domestic product }\end{array}$ & WBI \\
\hline
\end{tabular}

$$
L G D P P C_{t}=\alpha_{0}+L \alpha_{1} M S_{t}+\alpha_{2} I N T R_{t}+L \alpha_{3} G E X P_{t}+L \alpha_{4} G R E V_{t}+\alpha_{5} T R O_{t}+L \alpha_{6} G C F_{t}+\varepsilon_{t}
$$

Table 1 Source and computation of data 
Table 2 Summary of statistics

\begin{tabular}{lllccccc}
\hline & LGDPPC & LGCF & LGEXP & LGREV & INTR & LM2 & TRO \\
\hline Mean & 7.47894 & 28.5392 & 6.598485 & 7.060299 & 18.91367 & 7.150395 & 33.70649 \\
Median & 7.405035 & 28.8994 & 7.018636 & 7.782058 & 17.87167 & 7.447135 & 34.32022 \\
Maximum & 7.849285 & 30.50909 & 8.963639 & 9.316217 & 31.65 & 10.12981 & 53.27796 \\
Minimum & 7.195041 & 25.19074 & 2.568106 & 2.533363 & 9.599167 & 3.104553 & 9.135846 \\
Std. dev & 0.25121 & 1.703822 & 1.98462 & 2.148014 & 3.791596 & 2.369382 & 11.23017 \\
Skewness & 0.27013 & -0.60349 & -0.62433 & -0.731409 & 0.925691 & -0.30048 & -0.2982 \\
Kurtosis & 1.368511 & 2.028265 & 2.103023 & 2.208239 & 5.60809 & 1.715951 & 2.471383 \\
Jarque-Bera & 4.430455 & 3.601622 & 3.54558 & 4.150082 & 15.34463 & 3.014892 & 0.952679 \\
Probability & 0.109129 & 0.165165 & 0.169858 & 0.125551 & 0.000466 & 0.221475 & 0.621053 \\
\hline
\end{tabular}

v. $\frac{\partial G D P P C}{\partial I N T R}>0$; this implies that INTR should positively impact the GDPPC, because the interest rate is expected to encourage the surplus sector to save likewise encourages investors cum deficit sector to borrow which will all lead to increase in national output cum economic growth.

vi. $\frac{\partial G D P P C}{\partial M 2}>0$; this implies that M2 should positively impact the GDPPC, because when more money is in circulation it will ignites production and consumption which in turn stimulate economic growth.

vii. $\frac{\partial G D P P C}{\partial T R O}>0$; this implies that TRO should positively impact the GDPPC, because as an economy trades with other countries it expands her economy

\section{Results and discussion}

Table 2 summarizes the statistical information of the variables used in the study. The table shows that the means (average value) of gross domestic product per capital, gross capital formation, government expenditure, government revenue, interest rate, money supply and trade openness were 7.4789, 28.5392, 6.598485, 7.060299, 18.91367, 7.150395 and 33.70649, respectively. Also, the table shows that the mean value of GDPPC and IINTR were greater than their median values which implies that the distribution of GGDPPC and INTR are skewed to the right, suggesting that Nigeria has GDPPC and INTR that are lower than their average value. In addition, the mean value of gross capital formation, government expenditure, government revenue, money supply and trade openness were smaller than their median values suggesting that Nigeria has gross capital formation, government expenditure, government revenue, money supply and trade openness that are higher than their average values. Furthermore, the result reveals that TRO is the most unstable variable while GDPPC is the most stable variable as their standard deviation value where the highest
Table 3 Summary unit root test

\begin{tabular}{lrrr}
\hline Variables & \multicolumn{1}{l}{ ADF } & \multicolumn{1}{l}{ DF } & \multicolumn{1}{l}{ PP } \\
\hline At level & & & -0.29 \\
LGDPPC & -0.60 & -0.28 & $*{ }^{* *}-4.66$ \\
LGEXP & $* * *-4.64$ & -1.02 & ${ }^{* *}-4.23$ \\
LGREV & -2.47 & -0.30 & ${ }^{* *}-3.69$ \\
INTR & $* *-3.61$ & $* *-2.18$ & -2.21 \\
MS & $* *-2.62$ & -1.16 & 0.06 \\
TRO & -2.91 & -1.61 & $* * * 0.01$ \\
LGCF & $* * *-3.72$ & -1.16 & \\
First difference & & & $* * *-4.06$ \\
LGDPPC & $* * *-0.41$ & $* * *-3.53$ & $* * *-7.13$ \\
LGEXP & $* * *-7.31$ & $* * *-7.42$ & $* * *-91$ \\
LGREV & $* * *-5.91$ & $* * *-5.09$ & $* * 3.49$ \\
INTR & $* * *-6.89$ & $* * *-4.09$ & $* * *-9.47$ \\
MS & $* *-3.48$ & $* * *-3.16$ & $* * *-7.59$ \\
TRO & $* * *-7.37$ & $* * *-7.44$ & $* * *-4.27$ \\
INST*FD & $* * *-4.09$ & $* * *-4.09$ &
\end{tabular}

${ }^{*} 10 \%,{ }^{* *} 5 \%$, ${ }^{* * *} 1 \%$

and lowest, respectively. The table also reveals that all variables showed a high degree of consistency because their median and average values fall within the maximum and minimum values of the variables. Skewness statistics shows that GGDPPC, INTR and MS were positively skewed toward normality while GCF, GEXP, GREV and TRO were negatively skewed toward normality. Also, the kurtosis which measures the peakness of the distribution shows that all the variables were platykurtic except interest rate, meaning all the variables were flat in relative to normal distribution except interest rate. Lastly, the Jarque-Bera statistics shows that all the variables except interest rate were normally distributed at $5 \%$ significant level.

The study examines the time series properties of each variable used in the model to determine the stationary properties of each variable. It is sacrosanct to carry 
out this test to determine the state of stationarity of the variables as conducting regression analysis on non-stationary variable can lead to a fallacious regression. The study made use of three different test, namely augmented Dickey-Fuller, Phillips-Perron and Dickey-Fuller-GLS tests, to determine the stationarity of each variable. The results of the three tests as displayed in Table 3 shows that GGDPPC and trade openness were stationary at the first difference. Contrariwise, the three tests also show that interest rate was stationary at level. Other variables showed mixed results from the tests, for example, government expenditures turned out to be stationary at the first difference by augmented Dickey-Fuller and Phillips-Perron, but only became stationary at first difference in DF's test. Also, Phillips-Perron test reveal that government expenditure is stationary at level while augmented Dickey-Fuller and Dickey-Fuller-GLS shows it is stationary at the first difference. Although there were inconsistencies in the results of the tests as revealed in Table 3, there are consistent results across the three tests that demonstrate a mixed result of the level of stationarity of the variables as the three tests show that GDP per capita and trade openness were stationary at the first difference and that the interest rate was stationary at the level. Therefore, this study will employs ARDL technique as it is the estimation that accommodates variables with mix level of stationarity. ARDL was proposed by Pesaran et al. [28] to solve the puzzle created when variables have mix level of stationarity.

Sequel to the confirmation of the stationarity level of each variable the study uses the autoregressive distributed shift model (ARDL) and the error correction model (ECM) based on Pesaran et al. [29] to examine both the long- and short-run relationships among the variables of
Table 4 Bound test for cointegration

\begin{tabular}{llll}
\hline Significance level & F-statistics & $\begin{array}{l}\text { Lower bound } \\
\mathbf{I ( 0 )}\end{array}$ & $\begin{array}{l}\text { Upper } \\
\text { bound } \\
\mathbf{I}(\mathbf{1})\end{array}$ \\
\hline $5 \%$ & 6.10 & 2.27 & 3.28 \\
$1 \%$ & & 2.88 & 3.99 \\
\hline
\end{tabular}

Table 5 Long-run parameter estimates

\begin{tabular}{lcccc}
\hline Variable & Coefficient & SE & t-Statistic & Prob \\
\hline LOG(GDPPC(- 1))* & -0.80 & 0.089 & -8.93 & 0.00 \\
LOG(GCF) & -1.33 & 0.19 & -7.02 & 0.00 \\
LOG(GEXP) & 0.66 & 0.21 & 3.08 & 0.03 \\
LOG(GREV) & 0.64 & 0.06 & 10.42 & 0.00 \\
INTR & $-4.18 \mathrm{E}-05$ & 0.01 & -0.02 & 0.99 \\
LOG(M2) & -0.01 & 0.07 & -0.03 & 0.98 \\
TRO & -0.02 & 0.01 & -6.05 & 0.01 \\
C & 37.09 & 4.28 & 8.67 & 0.00 \\
\hline
\end{tabular}

interest. This estimation technique is the technique that accommodates variables with different level of stationarity that is stationary variables in the first difference $\mathrm{I}(0)$ and stationary variables in the first difference I(1); however, no level of integration of any variable should be higher than the first difference. Another advantage this estimation technique has over technique is that it is effective in a relatively small sample. It is sacrosanct to conduct bound test to know whether the model cointegrate. To implement the ARDL bound test procedure, an ARDL framework equation needs to be specify as it is written in Eq. (8)

$$
\begin{aligned}
\Delta L G D P P C_{t}= & \alpha_{0}+\beta_{1} L G D P P C_{t-1}+\beta_{2} L M S_{t-1}+\beta_{3} I_{N T R_{t-1}+\beta_{4} L G E X P_{t-1}+} \\
& \beta_{5} L G R E V_{t-1}+\beta_{6} T_{R O_{t-1}}+\beta_{7} L G C F_{t-1}+\sum_{i=1}^{q} \theta_{1 i} \Delta L G D P P C_{t-1}+\sum_{i=1}^{q} \theta_{2 i} \Delta L M S_{t-1}+ \\
& \sum_{i=1}^{q} \theta_{3 i} \Delta \operatorname{LINTR}_{t-1}+\sum_{i=1}^{q} \theta_{4 i} \Delta G E X P_{t-1}+\sum_{i=1}^{q} \theta_{5 i} \Delta L G R E V_{t-1}+\sum_{i=1}^{q} \theta_{6 i} \Delta T R O_{t-1}+ \\
& \sum_{i=1}^{q} \theta_{7 i} \Delta L G C F_{t-1}+\varepsilon_{t}
\end{aligned}
$$


where the variables are as defined previously/before $\theta_{1} t o \theta_{7}$ are the vector parameters of the short run, $\beta_{1}$ to $\beta_{7}$ are the long-run vector parameters, $\Delta$ is the operator of the first difference, $\mathrm{q}$ is the length of the optimal lag, $\alpha_{0}$ is the constant and $\varepsilon_{t}$ is the error term.

Following Pesaran et al. [30], this study employs F-test to determine whether the variables cointegrate. The null hypothesis is that the variables do not cointegrate that is there is no long-run relationship among the variable, whereas the alternative is that the variables cointegrate that is there is long-run relationship among the variables.

The null and alternative hypotheses are specified below as:
It also shows that gross capital formation, which is the measure of capital stock, has adversely impact GDP per capital, i.e., $1 \%$ increase in gross capital formation significantly reduced GDP per capital per $1.33 \%$. This denotes that in the long-run gross capital formation deters economic growth of Nigeria. It indicates that there has not been proper/efficient usage of the fund earmark for the maintenance of the country's productive assets and that the assets were not productively/efficiently utilized to enhance economic productivity. An example of such is the state of moribund the country's refineries which supposed to be producing refilled oil for local consumption and possibly exportation is even when government keeps spending on it. The non-functioning of the refineries has

$$
\begin{aligned}
& H_{o}: \beta_{1}=\beta_{2}=\beta_{3}=\beta_{4}=\ldots \ldots \ldots \ldots \ldots \ldots \ldots \ldots . . . \ldots \beta_{7} \\
& H_{1}: \beta_{1} \neq \beta_{2} \neq \beta_{3} \neq \beta_{4} \neq \ldots \ldots \ldots \ldots \ldots \ldots \ldots \ldots \ldots \neq \beta_{7}
\end{aligned}
$$

Along with the calculated F-statistic, the bound test provides two critical values [lower bound, $\mathrm{I}(0)$ and upper bound, $\mathrm{I}(1)$ ] that helps to determine whether the variables cointegrate that is there is long-run relationship among the variables. The rule is that when the value of $F$ statistic is lesser than the lower bound the variables do not cointegrate; however, when the value of the $F$ statistic is between the lower and upper bounds, the study cannot determine whether the variables cointegrate; lastly, where the F statistic is above the value of the upper bound, the study may conclude that the variables cointegrate. The result in Table 4 indicates that the variables cointegrate. (Long-run relationship exists among the variables.)

Once it is established that a cointegration exists in the model, the next step is to estimate the ARDL model (p, q1, q2, q3, q4) model to provide the long-term coefficients. made the country to be importing refined oil even when the country is a major oil producer in the world and this is costing the country some fortune which could have been used for other developmental project. As such, capital stock which is supposed to stimulate economic growth is adversely affecting economic growth. This contradicts the Cobb-Doulas production function/ endogenous growth model which accentuates capital as a vital input in economic growth. It is, however, in tandem with the study of $[32,33]$.

In a similar vein, the result reveals that trade openness significantly hinders gross domestic product per capital, i.e., $1 \%$ increment in trade openness significantly deterred the GDP per capita by approximately $0.02 \%$. This implies that trade openness (trade policy) adversely affects economic growth in Nigeria. It contradicts the theoretical argument of the Heckscher-Ohlin trade theory and classical theory of trade that postulated that trade promotes

$$
\begin{aligned}
& \Delta L G D P P C_{t}=\alpha_{0}+\sum_{i=1}^{p} \beta_{1} \Delta L G D P P C_{t-1}+\sum_{i=0}^{q 1} \beta_{2} \Delta L M S_{t-1}+\sum_{i=0}^{q 2} \beta_{3} \Delta L I N T R_{t-1}+ \\
& \sum_{i=0}^{q 3} \beta_{4} \Delta G E X P_{t-1}+\sum_{i=0}^{q 4} \beta_{5} \Delta L G R E V_{t-1}+\sum_{i=0}^{q 5} \beta_{6} \Delta T R O_{t-1}+\sum_{i=0}^{q 6} \beta_{7} \Delta L G C F_{t-1}+\varepsilon_{t}
\end{aligned}
$$

The result in Table 5 shows that GDPPC (-1), which is the previous GDP per capital negatively influence the current GDP per capital in Nigeria, since 1\% increment leads to $0.80 \%$ deterioration of the economy. This indicates that the previous income level adversely affects the country's current income level. This does not conform to the a priori expectation. economic growth. The reason for the result could be because the country's trade volume has been in favor of import and the country exports mainly primary product. The study is in tandem extant studies [24, 29, 32].

Contrariwise, the result reveals that government revenue significantly promotes gross domestic product per capital of Nigeria, i.e., $1 \%$ increment in government 
Table 6 Short-run parameters and the speed of adjustment

\begin{tabular}{lcccc}
\hline Variable & Coefficient & SE & t- Statistic & Prob \\
\hline DLOG(GDPPC(- 1)) & -0.06 & 0.06 & -0.89 & 0.41 \\
DLOG(GCF) & -0.01 & 0.01 & -0.49 & 0.64 \\
DLOG(GEXP) & 0.21 & 0.02 & 10.71 & 0.00 \\
DLOG(GREV) & 0.01 & 0.01 & 0.86 & 0.43 \\
D(INTR) & 0.03 & 0.01 & 19.27 & 0.00 \\
DLOG(M2) & -0.14 & 0.01 & -11.95 & 0.00 \\
D(TRO) & -0.01 & 0.01 & -10.62 & 0.00 \\
CointEq(- 1)* & -0.80 & 0.04 & -21.23 & 0.00 \\
R-squared & 0.99 & & & \\
Adjusted R-squared & 0.98 & & & \\
\hline
\end{tabular}

revenue triggered approximately $0.64 \%$ improvement in economic growth. This indicates that government revenue stimulates Nigeria's economic growth. It infers that government has been generating her tax revenue majorly from non-distortion taxes which has not adversely affects production and consumption of goods and services in the country. It also means that the nontax revenue which is majorly from crude oil has been instrumental to the country's economic growth. It is in tandem extant studies [34].

Also, government expenditure significantly propels economic growth of Nigeria, since $1 \%$ increment triggered $0.66 \%$ improvement in the country's economic growth. This indicates that government's injecting of fund to the public increases the purchasing power of the citizens, which in turn propel economic growth also it could be that the government is providing social infrastructure which is attracting investors and in turn propels economic growth. It aligned to the argument of Keynes as cited by Adegboyo and Olaniyan [30] that increased public spending do boost the economy through the infusion of purchasing power into the economy. This is in tandem with the study of Agu et al. [12]. In sum, the two variables that were used to capture fiscal policy promote the growth of the economy, and this implies that in the long run fiscal policy stimulates the country's economic growth. The study is in tandem with extant studies [35-37].

In sum, the two parameters used to capture monetary policy did not affect economic growth; this suggest that monetary policy has not been effective and has not affected Nigeria's long-term economic growth. This negates the theoretical argument of Friedman and Hahn [31] which noted that monetary policy instigates the growth of the economic.

The short-run model which is also the error correction model (ECM) is estimated with Eq. (9).
Table 7 Diagnostic test

\begin{tabular}{lll}
\hline Diagnostic test & F-Statistic & Prob. value \\
\hline Breusch-Godfrey serial correlation LM test & 0.41 & 0.45 \\
Heteroskedasticity test: Breusch-Pagan & 0.52 & 0.91 \\
Godfrey & 1.01 & 0.61 \\
Normality test: Jarque-Bera & & Stable \\
CUSUM & & Stable \\
CUSUM of square & & \\
\hline
\end{tabular}

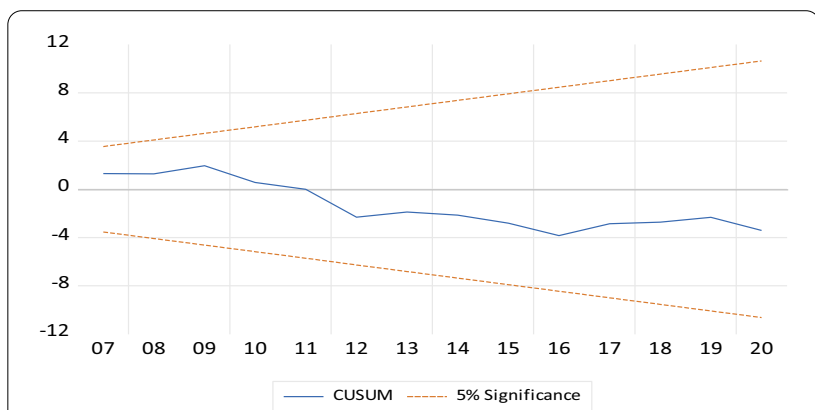

Fig. 1 Cumulative sum of recursive residuals (CUSUM)

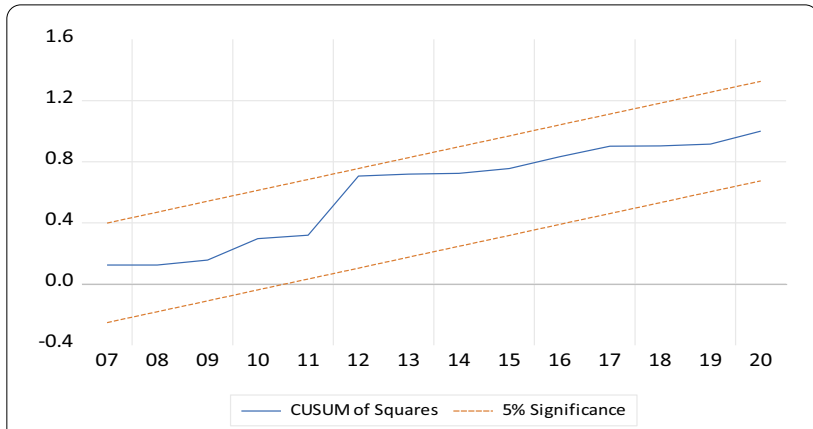

Fig. 2 Cumulative sum of squares of recursive residuals (CUSUMSQ)

$$
\begin{aligned}
\Delta L G D P P C_{t}= & \alpha_{0}+\sum_{i=1}^{p} \theta_{1 i} \Delta L G D P P C_{t-1}+\sum_{i=0}^{q 1} \theta_{2 i} \Delta L M S_{t-1} \\
& +\sum_{i=0}^{q 2} \theta_{3 i} \Delta L I N T R_{t-1}+\sum_{i=0}^{q 3} \theta_{4 i} \Delta G E X P_{t-1} \\
& +\sum_{i=0}^{q 4} \theta_{5 i} \Delta L G R E V_{t-1}+\sum_{i=0}^{q 5} \theta_{6 i} \Delta T R O_{t-1} \\
& +\sum_{i=0}^{q 6} \theta_{7 i} \Delta L G C F_{t-1}+\lambda E C T_{t-1}+\varepsilon_{t}
\end{aligned}
$$

where $\mathrm{ECT}_{t-1}$ is the error correction term and must be negative and statistically significant for it to be well define. 
The result in Table 6 indicates that government expenditure positively influence economic growth that is $1 \%$ increase in public spending causes Nigeria's economic growth to increase by $0.21 \%$.

Similarly, the result shows that the 1 percent increase in the interest rate substantially increases gross domestic product per capital by 0.03 percent. This shows that interest rate impels Nigeria economic growth in the short run. This is consistent with liquidity preference theory and loanable funds theory and is in tandem with the work of [38, 39]. This implies that interest rate is effective in attracting investors, at it encourages the surplus sector to save likewise encourages investors cum deficit sector to borrow which will all lead to increase in national output cum economic growth. This deviates from the result of the long run.

Money supply (M2) short-run result diverges from the long-run result. The short-run result shows that $1 \%$ increase in money supply (M2) deters economic growth by $0.14 \%$. This could be that the money supply in the circulation ignites increase in prices of goods which in turn dissuade production and consumption and consequently hampers economic growth of Nigeria. Trade openness hinders Nigeria's economic growth significantly as $1 \%$ increase in trade opening will reduce economic growth by $0.01 \%$. This implies that open trade (trade policy) is a disincentive to the country's economic growth in the short term. It is in line with the result of the long term.

The ECM (-1) measures the speed of adjustment back to long-run equilibrium after a short-run shock is well defined as it is negatively significant. The result shows that the model converges back to long equilibrium at the speed rate of $80.06 \%$ following a short-run shock, and this implies that 80.06 percent of the preceding year's economic growth (GDPPC) disequilibrium has been corrected by government expenditure, government revenue, interest rate, money supply and trade openness. It means that the current value of economic growth will adjust to change in government expenditure, gross capital formation, government revenue, interest rate, money supply and trade openness.

The coefficients of determination (R2) show that the explanatory variables used in the study are responsible for approximately $99.21 \%$ of the total change in economic growth. It indicates that the variables used in the model are appropriate to be analysis.

\section{Diagnostic test}

The results of the diagnosis tests are shown in Table 7. It reveals that the probability value of all the test were higher than $5 \%$ significant level meaning that the null hypothesis of nonexistence of heteroskedasticity, serial correlation and non-normality test were not rejected which implies that there is no homoscedastic variances and serial correlation in the model, and the model is normally distributed.
In addition, to verify model stability, the study uses the cumulative sum of recursive residues (CUSUM) and the cumulative sum of recursive residue squares (CUSUMSQ) as presented in Figs. 1 and 2, respectively. The graph shows that residues fall within the $95 \%$ confidence inter$\mathrm{val} / 5$ critical limits (limits), meaning that the model is stable over the estimation period. In summary, the results reveal that the model had no econometric problems.

\section{Conclusions}

Investigations have been conducted into how different government policies affect economic growth with emphasis on fiscal, monetary and trade policies. Most of the extant studies focus on individual policy to determine how it affects the economic growth, with very few merging two of the policies. This study will be different as it combines the three policies together to determine how each one affects the economy. Therefore, this paper explores the impact of fiscal, monetary and trade policies on Nigeria's economic growth from 1985 to 2020. The study captures fiscal policies with government expenditure and government revenue, monetary policies with money supply (M2) and interest rate, and trade policy with trade openness. The work adopts three unit root test, namely Dickey-Fuller-GLS, augmented DickeyFuller and Phillips-Perron tests, to determine the level of stationarity of each variable, and the results indicates that there is a mixed level of stationarity in the variables, consequently the study employs ARDL estimation technique as it is the technique that accommodates variables with mix level of stationarity. The bound test result shows that the variables cointegrate. (The variables had long-run relationship.) The ARDL long-run result reveals that fiscal policies (government revenue and government expenditure) stimulate Nigeria's economic growth, and this is in tandem with extant studies [14, 15, 40]. Contrariwise, trade policies (trade openness) deter Nigeria's economic growth; thus, it is in tandem extant studies [24, 29, 32]. The short-run result shows that the fiscal policies had an inconsistent impact on Nigeria's economic growth and thus differs from the long-run result, and while government spending continues to drive economic growth in Nigeria, government revenues have no effect on the growth of the economy. Also, monetary policies had an inconsistent impact on the growth of the economy and differs from the result of the long run, interest rate impels growth of the economy, and this is in line with previous studies [38, 39], while money supply deters the growth of Nigeria's economy; lastly, the trade policies maintain her negative influence on the economy in both the long run and short run. The result of the diagnostic test showed that the model was free of econometric problems. Sequel to the findings, the study recommends the 
following: policymakers should place more emphasis on using fiscal policy which was found to be stimulating the country's growth rate. Whenever it is expedient to use monetary policy to stimulate economic growth, policy makers should make use of interest rates as it stimulates the growth of the economy in the short run. The government should review her trade policies to reduce import by encouraging consumption of local products and motivate exporters of goods (raw material) to refine the products before exporting such.

\begin{abstract}
Abbreviations
ARDL: Autoregressive distributed lag; ECM: Error correction model; UNCTAD: United Nations Conference on Trade and Development; GDPPC: Gross domestic product per capital; MS: Money supply (M2); INTR: Interest rate; GEXP: Total government expenditure; GREV: Total government revenue; TRO: Trade openness; GCF: Gross capital formation; CBN: Central Bank of Nigeria; WBI: World Development Indicators.
\end{abstract}

\section{Acknowledgements}

Not applicable

\section{Authors' contributions}

OSA wrote the method, collated data, analyzed and interpreted the data, and transcribed the conclusion and policy recommendations. SAK worked on introduction. OTF worked on the literature review. All authors have read and approved the manuscript.

\section{Funding}

Not applicable.

\section{Availability of data and materials}

This is available on request.

\section{Declarations}

\section{Competing interests}

There are no competing interests among the authors.

Received: 22 March 2021 Accepted: 27 September 2021

Published: 18 October 2021

\section{References}

1. Adeeb B (2013) Do Fiscal, monetary and trade policies matter for growth? Empirical evidence from Pakistan. Dissertation, Mohammad Ali Jinnah University, Islamabad

2. Idris M, Bakar R, Ahmad TST (2018) The effects of fiscal operations on economic growth and stability in Nigeria: empirical evidence based on time series data. Int J Account Econ Stud 6(1):36-47

3. Idris M, Bakar R (2017) Fiscal operations and macroeconomic growth: the Nigerian experience. Int J Soc Admin Sci 2(1):31-44. https://doi.org/10. 18488/journal.136.2017.21.31.44

4. Nwosa P, Keji S, Adegboyo S, Fasina O (2020) Trade openness and unemployment rate in Nigeria. Oradea J Bus Econ 5(2):52-62

5. United Nation Conference on Trade and Development UNCTAD (2013) The impact of trade on employment and poverty reduction. TD/B/C/1/29. https://unctad.org/en/PublicationsLibrary/tdr2014_en.pdf. Accessed 10 Jan 2021

6. Idris M, Ahmad TST (2017) The productivity of public debt borrowing and economic growth in Sub-Saharan region: the Nigerian context. Int J Econ Comm Manage 5(6):340-373

7. Khattry B, Rao JM (2002) Fiscal faux pas? An analysis of the revenue implications of trade liberalization. World Dev 30:1431-1444
8. Kemal AR, Siddiqui R, Siddiqui R, Kemal MA (2003) An assessment of the trade liberalization on welfare in Pakistan: a general equilibrium analysis. Micro Impact of Macroeconomic Adjustment Policies (MIMAP) Technical Paper Series, 16, Pakistan Institute of Development Economics. http:// www.pide.org.pk/Mimap/MIMAP16.pdf. Accessed 5 Jan 2021

9. Martes E (2018) The effect of trade openness on unemployment: Longrun Versus Short-run. https://thesis.eur.nl/pub/43403/. Accessed 28 Dec 2020

10. Amassoma D, Keji S, Emma-Ebere OO (2018) The offshoot between money supply and inflation in Nigeria. J Econ Cooper Dev 39(1):83-108

11. Idris M, Bakar R, Ahmad TST (2017) The effects of fiscal deficits in developing countries: implications on the economic growth of Nigeria. Int I Soc Sci Econ Res 2(9):4497-4520

12. Agu SU, Okwo IM, Ugwunta OD, Idike A (2015) Fiscal policy and economic growth in Nigeria: emphasis on various components of public expenditure. SAGE Open 5(4):21582440156

13. Babalola SJ, Aminu U (2011) Fiscal policy and economic growth relationship in Nigeria. Int J Bus Soc Sci 2(17):235-247

14. Onwe OJ (2014) Impacts of fiscal policy components on economic growth in Nigeria: an empirical trend analysis. Arab J Bus Manage Rev 4(1):178-192

15. Mobolaji H, Ehigiamusoe KU, Lean HH (2015) Role of fiscal policy in inclusive growth in Nigeria. Nigerian J Econ Soc Stud 57(2):253-269

16. Chinedu UA, Daniel OC, Ezekwe UC (2018) Sectoral spreads of government expenditures and economic growth in Nigeria: an approach of error correction model. Int J Acad Res Econ Manage Sci 7(4):181-195. https://doi.org/10.2307/1912517

17. Ayomitunde AT, Olaniyi OO, Zannu SM, Stephen BA (2018) Monetary policy and economic growth in Nigeria: an ARDL-bound testing and ECM approach. Eur J Econ Law Politics 6(4):1-11

18. Onyeiwu C (2012) Monetary policy and economic growth of Nigeria. J Econ Sustain Dev 3(7):62-70

19. Sulaiman LA, Migiro SO (2014) The nexus between monetary policy and economic growth in Nigeria: a causality test. Public Municipal Finance 3(2):35-40

20. Adigwe PK, Echekoba FN, Onyeagba BC (2015) Monetary policy and economic growth in Nigeria: a critical evaluation. J Bus Manage 7(2):110-119

21. Fasanya IO, Onakoya ABO, Agboluaje MA (2013) Does monetary policy influence economic growth in Nigeria? Asian Econ Financ Rev 3(5):635-646

22. Afolabi Al, Sotan KA, Salahudeen SO (2020) Trade policy and economic growth in Nigeria. Econ Thought J 5:84-99

23. Afolabi B, Danladi JD, Azeez MI (2017) International trade and economic growth in Nigeria. Glob J Human Soc Sci Econ 17(5):428-439

24. Balogun ED (2016) Trade policy incentives and economic growth in Nigeria. World Acad Sci Eng Technol Int J Mech Ind Eng 10(6):1965-1975

25. Bodunrin OS (2016) The impact of fiscal and monetary policy on Nigerian economic growth. https://mpra.ub.uni-muenchen.de/92811/. Accessed 5 Jan 2021

26. Ajayi MA, Aluko OA (2017) Evaluating the relative impact of monetary and fiscal policy in Nigeria using the St. Louis equation. Acta Universitatis Danibus Economica 13(1):456-471

27. Ishola V, Titiloye T (2020) Effect of fiscal policy and monetary policy on economic growth in Nigeria: a time series analysis. doi:https://doi.org/10. 2139/ssrn.3706157. Accessed 28 Dec 2020

28. Pesaran MH, Shin Y, Smith RJ (2001) Bounds testing approaches to the analysis of level relationships. J Appl Economet 16(3):289-326. https:// doi.org/10.1002/jae.616

29. Duodu E, Baidoo ST (2020) How does quality of institutions affect the impact of trade openness on economic growth of Ghana? Cogent Econ Finance 8(1):1812258. https://doi.org/10.1080/23322039.2020.1812258

30. Olufemi AS, Oladipo ON (2021) The viability of public expenditure in stimulating economic growth in Nigeria (mediating on the role of public sector). Acta Universitatis Danubius 17(1):70-86

31. Friedman BH, Hahn FH (1990) Handbook of monetary economics. NorthHolland, New York,

32. Sakyi D (2011) Trade openness, foreign aid and economic growth in postlibralisation Ghana: an application of ARDL bound-test. J Econ Int Finance 3(3):146-156 
33. Hongwane TM, Mongale IP, Tala L (2018) Analysis of the impact of fiscal policy on econpmic growth in South Africa: VECM approach. J Econ Behav Stud 10(2):231-238

34. Nazir R, Anwar M, Shoukat A (2013) Does fiscal policy matter for growth? Empirical evidence from Pakistan. Int J Econ Financ 5(3):205-212

35. Ocran K (2011) Fiscal policy and economic growth in South Africa. J Econ Stud 38(5):604-618

36. Leshoro TLA (2007) An empirical analysis of disaggregated government expenditure and economic growth in South Africa. UNISA Economic Research Working Paper Series, Working Paper No.10/2017, Department of Economics, University of South Africa

37. Thamae R (2013) The growth of government spending on Lesotho. J Econ Anal Policy 43(3):339-352
38. Maiga FK (2017) Impact of interest rate on economic growth in Nigeria. Pyrex J Bus Finance Manage Res 3(3):98-111

39. Jelilov $G$ (2016) The impact of interest rate on economic growth example of Nigeria. J Soc Sci 6(2):51-64

40. Takyi PO, Twum A (2015) Do monetary, fiscal and trade policies matter for economic growth?: Ghana's experience. Glob Bus Econ Res J 4(3):1-16

\section{Publisher's Note}

Springer Nature remains neutral with regard to jurisdictional claims in published maps and institutional affiliations.

\section{Submit your manuscript to a SpringerOpen ${ }^{\circ}$ journal and benefit from:}

- Convenient online submission

- Rigorous peer review

- Open access: articles freely available online

- High visibility within the field

- Retaining the copyright to your article

Submit your next manuscript at $\boldsymbol{\nabla}$ springeropen.com 